\title{
PENGARUH GOOD CORPORATE GOVERNANCE DAN PROFITABILITAS TERHADAP NILAI PERUSAHAAN
}

\author{
Maria Silvia Coo Menge dan Kartika Nuringsih \\ Program Studi Manajemen Fakultas Ekonomi Universitas Tarumanagara, Jakarta \\ e-mail:mariaa.silviaa99@gmail.com
}

\begin{abstract}
Abstact: The research objective was to determine the effect of good corporate governance which is proxied by managerial and institutional ownership and the effect of profitability in predicting firm value (Tobin Q) in the manufacturing industry in the consumer goods sector listed on the Indonesia Stock Exchange for the 2017-2019 period. The study involved 11 companies that were collected based on purposive sampling. Data in the form of company financial reports are obtained through the Indonesia Stock Exchange website. Data processing using Eviesw10 software with the results of the variable good corporate governance, especially managerial ownership, has a significant positive effect on firm value, while institutional ownership does not have a significant effect. Furthermore, profitability has a significant positive effect on firm value. The results of this study can be used as an example of a mechanism for suppressing agency conflict and as a reference in conducting studies on the creation of corporate value.
\end{abstract}

Keywords: Good corporate governance, managerial ownership, institusional ownership, profitability, firm value.

Abstrak: Tujuan penelitian adalah untuk mengetahui pengaruh good corporate governanceyang diproksi dengan kepemilikan manajerial dan institusionalserta efek profitabilitas dalam mempredikasikan nilai perusahaan (Tobin Q) pada industri manufaktur sektor barang konsumsi terdaftardi Bursa Efek Indonesia periode 2017-2019. Penelitian melibatkan 11 perusahaan yang dikumpulkan berdasarkan purposive sampling. Data berupa laporan keuangan perusahaan diperoleh melalui situs Bursa Efek Indonesia. Pengolahan data menggunakan software Eviesw10 dengan hasil variabel good corporate governancekhususnya kepemilikan manajerial berpengaruh signifikan positif signifikan terhadap nilai perusahaan sebaliknya kepemilikan institusional tidak berpengaruh signifikan. Selanjutnya profitabilitas berpengaruhi secara positif signifikan terhadap nilai perusahaan. Hasil penelitian ini dapat digunakan sebagai salah satu contoh mekanisme menekan konflik keagenan serta sebagai referensi dalam melakukan kajian terhadap penciptaan nilai perusahaan.

Kata kunci: Good corporate governance, kepemilikan manajerial, kepemilikan institusional, profitabilitas, nilai perusahaan.

\section{LATAR BELAKANG}

Era globalisasi saat ini menuntut semua perusahaan untuk memaksimalkan kinerjanya. Hal ini berkaitan dengan tujuan utama perusahaan yaitu untuk meningkatkan kesejahteraan pemegang saham dan nilai perusahaan sebagai indikator untuk mengukur tingkat kesejahteraan pemegang saham. Jika harga saham makin tinggi maka makin tinggi nilai perusahaan dan tingkat kesejahteraan pemegang saham (Brigham dan Gapenski, 1996 dalam Handayani dkk, 2020). Tobin's Q digunakan untuk menilai peluang investasi, kinerja manajemen, dan kesalahan harga saham (Sulong et al, 2013 dalam Margarita et al, 2019). 
Dalam menjalankan perusahaan seringkali terjadi konflik antara pemilik perusahaan (principal) dan manajemen (agen) yang disebut masalah keagenan. Relevan dengan penelitian sebelumnya (Jensen dan Meckling, 1976 dalam Susanto dan Nuringsih 2020) yang menyatakan bahwa manajer sering melakukan perilaku oportunistik untuk menguntungkan pihak tertentu, atau dirinya sendiri, yang mengakibatkan konflik keagenan.Dengan potensi konflik kepentingan yang mungkin muncul, prinsipal wajib memantau keputusan manajer, namun hal tersebut meningkatkan biaya agensi yang dapat mengurangi kinerja perusahaan. Oleh karena itu, perusahaan harus bijak dalam menyeimbangkan biaya yang terkait dengan hubungan keagenan untuk meningkatkan kinerja perusahaan. Untuk itu tata kelola perusahaan perlu dilaksanakan dengan baik, yaitu dengan mensejajarkan kepentingan manajer dan kepentingan pemilik melalui mekanisme good corporate governance diantaranya kepemilikan manajerial dan kepemilikian institusional. Semakin tinggi tingkat kepemilikan manajerial dan kepemilikan institusional, maka dapat mengurangi masalah keagenan sehingga mampu meningkatkan nilai perusahaan.

Di samping itu, rasio profitabilitas mencerminkan keberhasilan/kegagalan perusahaan dan digunakan untuk menilai kemampuan suatu perusahaan dalam memperoleh keuntungan serta menjadi alat ukur tingkat efektivitas perusahaan (Robinso dkk, 2015; Lartey dkk., 2013 dalam Abdul Aziz, 2017). Dengan mengacu pada Return on Equity sebagai proksi profitabilitas yang menggambarkan berapa besar pendapatan dihasilkan oleh perusahaan untuk pengembalian saham ekuitas dari pemegang saham sehingga diharapkan mampu dijadikan sebagai mekanisme untuk meningkatkan nilai perusahaan.

Industri manufaktur berperan penting dalam meningkatkan nilai investasi dan ekspor dengan kontribusi terhadap PDB sebesar $20 \%$ dan ekspor $74 \%$ serta menjadi basis produksi dan terbesar di ASEAN dengan kontribusi sebesar 20,27\% (Kemenperin.go.id). Sektor consumer goods menjadi incaran bagi para investor terhadap saham-sahamnya karena potensi bisnis yang fundamental dan produk-produk industri ini menjadi barang konsumsi masyarakat (Astronacci.com). Berangkat dari pemaparan latar belakang tersebut, diputuskan untuk melakukan penelitian mengenaik efek good corporate governance dan profitabilitas dalam memprediksi nilai perusahaan di sector manufaktur kususnya barang konsumsi.

Pertimbangan pemilihan sector ini dikarenakan sector ini memiliki kontribusi relatif besar terhadap pendapatan nasional. Selain itu, ketergantungan masyarakat terkadap sektor ini juga tinggi sehingga tingkat permintaan terhadap barang konsumsi dipastikan cenderung meningkat. Sebagai ilustrasi pada tahun 2017 industri inimemiliki laju pertumbuhan pendapatan sebesar 8,3\% dan tertinggi dibandingkan negara-negara Asia Tenggara. Dengan demikian pertumbuhan tersebut berpengaruh terhadap kinerja perusahaan sehingga dilakukan penelitian terhadap nilai perusahaan. Sejalan dengan konsep tata kelola perusahaan maka dilibatkan aspek kepemilikan saham sebagai proksi dari tata kelola perusahaan yang baik supaya dapat mendorong profitabilitas sehingga berdampak positif dalam pembentukan nilai perusahaan.

\section{KAJIAN TEORI}

\section{Gambaran Umum Teori}

Teori yang digunakan dalam penelitian ini adalah teori keagenan(Jensen dan Meckling, 1976 dalam Susanto dan Nuringsih, 2020) yang menyatakan bahwa terjadi pemisahan fungsi kepemilikan dan manajemen perusahaan karena pemilik mendelegasikan tugas dan wewenang kepada manajer untuk mengelola perusahaan. Ketidakpastian dalam hubungan keagenan disebabkan oleh informasi asimetri, yang mengacu pada situasi dimana salah satu pihak dalam 
hubungan memiliki informasi banyak dari pihak lainnya (Zu \& Kaynak, 2012 dalam Subasinghage et al., 2014).

\section{Definisi Konseptual}

Nilai perusahaanmerupakannilai pasar yangmampu memberikan kekayaan maksimal kepada pemegang saham jika harga saham perusahaan meningkat (Nurlela dan Islahudin, 2008 dalam Kamalia, 2020).

Good Corporate Governance merupakansistem dan serangkaian proses yang digunakan perusahaan untukmengarahkan dan mengendalikan perusahaan dengan maksuduntuk menyeimbangkan kepentingan individu, perusahaan, dan masyarakat (Cadburry, 1992 dan Mallin, 2007 dalam Christoph, 2014).

Profitabilitasmerupakan hasil akhir dari serangkaian kebijakan dan pengambilan keputusan manajemen terkait dengan sumber dan pemanfaatan pendanaan untuk menjalankan perusahaan yang tertulis dalam laporan keuangan dan neraca perusahaan (Brigham dan Houston, 2001 dalam Ida et al., 2019).

\section{Hubungan Antara Varibel dan Perumusan Hipotesis}

Praktik tata kelola perusahaan yang baik mampu meningkatkan kinerja perusahaandan nilai perusahaan (Fama dan Jensen, 1983; Weisbach, 1988; Agrawal dan Knoeber, 1966; Su dan He, 2012 dalam Li Liu dkk, 2018). Melalui kepemilikan manajerial Jensen dan Meckling (1976) dalam Nurleni dkk (2008) menemukan bahwa kepemilikan manajerial mampu menjadi mekanisme yang dapat mengurangi masalah keagenan.

Menurut Short dan Kaesey (1999) dan Weir dkk (2002) dalam Basid Al-Najjar dan Dana Al-Najjar (2017) tingkat kepemilikan institusional yang tinggi mampu memberikan kontrol dan pemantauan yang lebih besar terhadap manajemen sehingga mampu meningkatkan kinerja dan nilai perusahaan. Saidi (2004) dalam Ignatius dkk (2017) profitabilitas merupakan kemampuan suatu perusahaan dalam upaya memperoleh laba atau keuntungan. Semakin tinggi profitabilitas suatu perusahaan, hal ini menunjukkan bahwa kinerja perusahaan tersebut dalam kondisi baik, sehingga dapat meningkatkan nilai perusahaan dan juga harga saham serta kesejahteraan pemegang saham.

Suhadak (2019) menemukan good corporate governance tidak berpengaruh signifikan terhadap financial performance dan nilai perusahaan. Penelitian Ida Bagus dkk (2019) menyatakan corporate governance, corporate profitability, dan corporate social responsibility disclousure berpengaruh positif signifikan terhadap nilai perusahaan. Penelitian Kamaliah (2020) menyatakan bahwa corporate governance berpengaruh langsung terhadap nilai perusahaan. Selanjutnya penelitian yang dilakukan Basil dan Dana (2017) menyatakan bahwa terdapat hubungan positif antara kebutuhan external financing dan nilai perusahaan. Menurut Worokinasih et al (2020) good corporate governance memiliki dampak yang signifikan positif terhadap nilai perusahaan. Ferdinand et al (2013) dalam penelitiannya menemukan bahwa terdapat hubungan yang positif antara corporate governance dan nilai perusahaandan hubungan negative antara reporting quality dan nilai perusahaan. Penggambaran model penelitian sebagai berikut: 


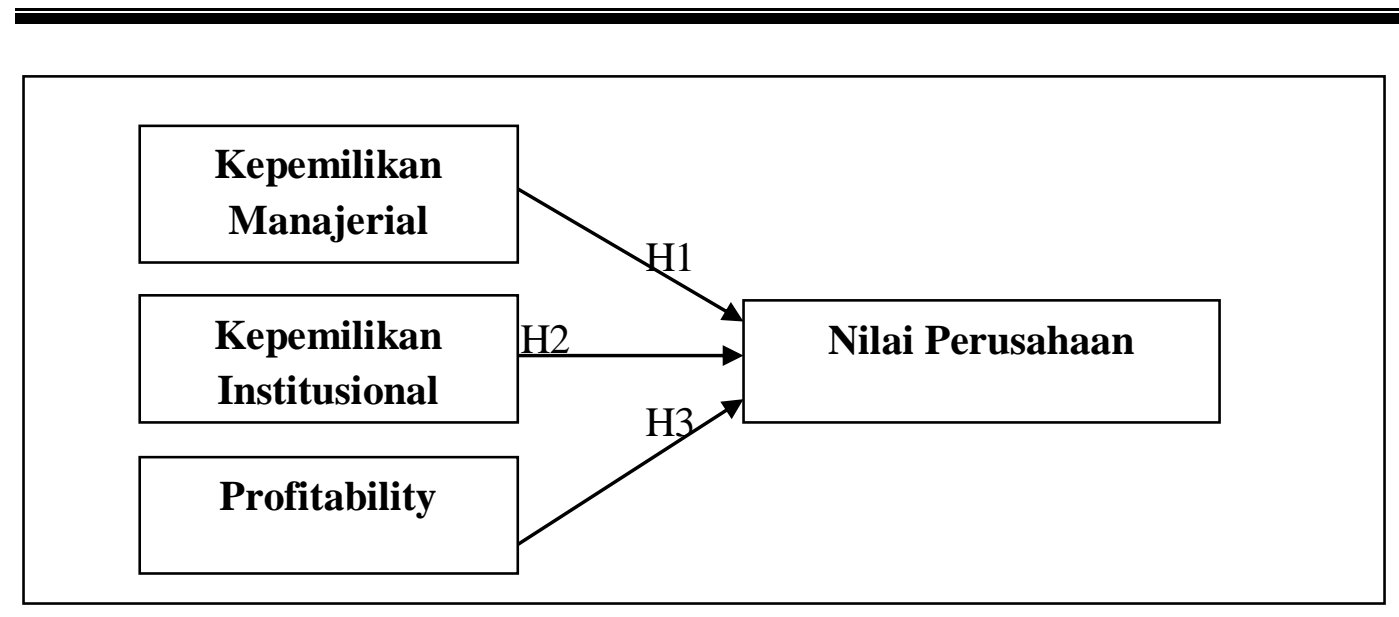

\section{Gambar 1. Model Penelitian}

Berdasarkan Gambar 1 dirumuskan hipotesis sebagai berikut:

H1: Kepemilikan manajerialberpengaruh positif terhadap nilai perusahaan.

$\mathrm{H} 2$ : Kepemilikan institusional berpengaruh positif terhadap nilai perusahaan

H3: Profitabilitas berpengaruh positif terhadap nilai perusahaan.

\section{METODE PENELITIAN}

Penelitian ini bersifat deskriptif dan metode kuantitatif. Variabel independen meliputi good corporate governance (GCG) terdiri dua variabel yaitu kepemilikan manajerial (X1) dan kepemilikan institusional (X2). Selain itu model penelitian menempatkan profitabilitas sebagai X3. Ketiga variabel tersebut yang digunakan untuk memprediksi nilai perusahaan yang diposisikan sebagai variabel dependen. Kepemilikan manajerial (managerial ownership) diukur berdasarkan perbandingan jumlah saham yang dimiliki oleh jajaran manajer dan komisaris dibandingkan dengan jumlah saham beredar. Sementara itu pengukuran kepemilikan institusional (institusional ownership) berdasarkan perbandingan jumlah saham yang dimiliki institusi lain (kelompok mayoritas) dibandingkan dengan jumlah saham beredar. Profitabilitas diukur melalui return on equity yang menunjukan perbandingan antara jumlah laba bersih dibagi total ekuitas. Untuk nilai perusahaan diproksi menggunakan Tobin Q dengan formulasi penjumlahan market value equity dan book value liability kemudian dibagi dengan book value atas total aset. Nilai indek Tobin yang baik di atas angka 1.

Data laporan keuangan diambil dari laporan keuangan perusahaan manufaktur sektor barang konsumsi yang terdaftar di BEI tahun 2017-2019 dengan menggunakan data panel (pooled data) selama 3 tahun dengan 11 perusahaan. Populasi diambil dari perusahaanperusahaan yang bergerak di barang konsumsi yang terdaftar di Bursa Efek Indonesia tahun 2017-2019. Teknik pemilihan sampel menggunakan metode non-probability sampling khususnya purposive samplingsehingga setelah dilakukan purposive samplingdari 62 perusahaan dapat terpilih 11 perusahaan sebagai sampel. Data-data tersebut kemudian dikumpulkan ke dalam Microsoft Excel dan diolah menggunakan software Eviews10. Untuk memenuhi persyaratan dalam panel data maka dilakukan pengujian uji Chow dan uji Hausman. 


\section{HASIL ANALISIS DATA}

\section{Statistik Deskriptif}

Tabel 1. Hasil Statistik Deskriptif

\begin{tabular}{lcccc}
\hline \hline & $\begin{array}{c}\text { KEPEMILIKAN } \\
\text { MANAJERIAL }\end{array}$ & $\begin{array}{c}\text { KEPEMILIKAN } \\
\text { INSTITUSIONAL }\end{array}$ & PROFITABILITY & $\begin{array}{c}\text { NILAI } \\
\text { PERUSAHAAN }\end{array}$ \\
\hline \hline Mean & 18.11948 & 66.32396 & 0.107036 & 1.473085 \\
Median & 0.756300 & 75.54590 & 0.119000 & 1.159900 \\
Maximum & 80.53300 & 95.23810 & 0.238600 & 3.885300 \\
Minimum & 0.015700 & 23.52110 & -0.178100 & 0.164500 \\
Std. Dev. & 28.82871 & 21.62633 & 0.099699 & 1.106889 \\
Skewness & 1.336784 & -0.667764 & -1.341221 & 0.845939 \\
Kurtosis & 3.112130 & 2.277433 & 4.353273 & 2.543057 \\
& & & & \\
Jarque-Bera & 9.845743 & 3.170389 & 12.41190 & 4.222964 \\
Probability & 0.007278 & 0.204908 & 0.002017 & 0.121058 \\
& & & & \\
Sum & 597.9429 & 2188.691 & 3.532200 & 39.61180 \\
Sum Sq. Dev. & 26595.02 & 14966.35 & 0.318074 & 33 \\
Observations & 33 & 33 & 33 & \\
Sumber: Hasil pengolahan Eviews 10 & &
\end{tabular}

Hasil uji statistik deskriptif menunjukkan nilai kepemilikan manajerial tertinggi adalah Indofood CBP Sukses Mkmur Tbk. dan terendah adalah Tunas Baru Lampung Tbk. Perusahaan sampel dengan nilai kepemilikan intitusional terbesar adalah Buyung Poetra Sembada Tbk. pada 2017 sedangkan terendah adalah Langgeng Makmur Industri Tbk. pada 2017-2019. Perusahaan memiliki nilai profitabilitas terbesar adalah Tunas Baru Lampung Tbk. pada 2017 dan terendah adalah Kedaung Indah Can Tbk. pada 2018.

\section{Pengujian Model Data Panel}

Redundant Fixed Effects Tests

\section{Tabel 2. Hasil Uji Chow}

Equation: Untitled

Test cross-section fixed effects

\begin{tabular}{lcrr}
\hline \hline Effects Test & Statistic & d.f. & Prob. \\
\hline \hline Cross-section F & 23.997822 & $(10,19)$ & 0.0000 \\
Cross-section Chi-square & 86.206064 & 10 & 0.0000 \\
\hline \hline
\end{tabular}

Sumber: hasil pengolahan Eviews10

Hasil uji Chow menunjukkan bahwa nilai probabilitas Cross-section $F$ dan Cross-section Chi Square masing-masing 0,0000 dimana nilai probabilitasnya $<0,05$. Hal ini menunjukkan bahwa fixed effects model digunakan dalam penelitian ini untuk mengestimasi data panel. 
Tabel. 3 Hasil Uji Hausman

Correlated Random Effects - Hausman Test

Equation: Untitled

Test cross-section random effects

\begin{tabular}{lrrr}
\hline \hline Test Summary & $\begin{array}{r}\text { Chi-Sq. } \\
\text { Statistic }\end{array}$ & Chi-Sq. d.f. & Prob. \\
\hline \hline Cross-section random & 7.394597 & 3 & 0.0603
\end{tabular}

Sumber: Hasil pengolahan Eviews10

Berdasarkan hasil uji Hausman, diperoleh nilai probability value chi-square adalah 0,0603atau >dari 0,05. Hal ini berarti pada penelitian ini menggunakan random effects model untuk mengestimasi data panel.

\section{Hasil Analisis Regresi Linear Berganda}

Tabel.4 Hasil Regresi Linear Berganda

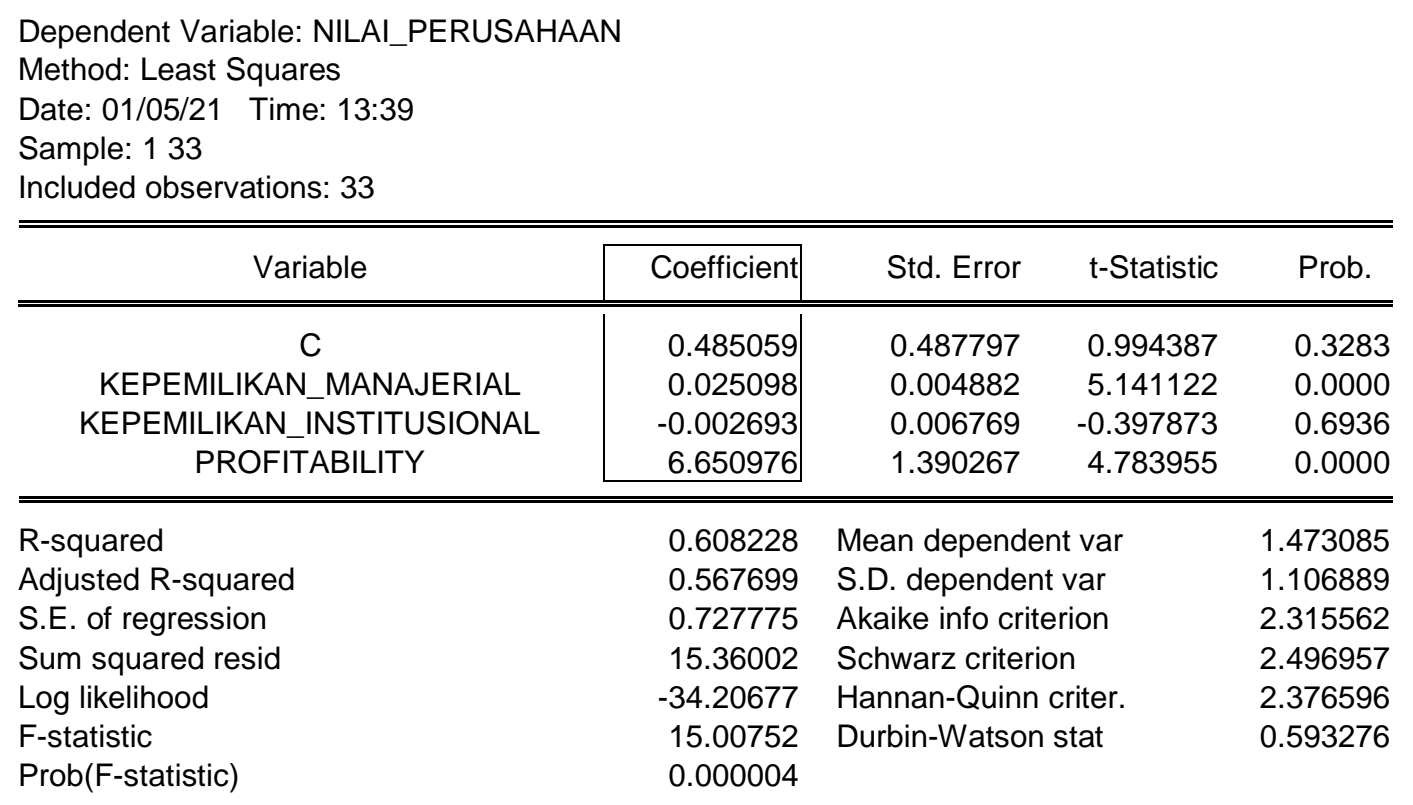

Sumber: hasil pengolahan Eviews10

Nilai signifikansi probabilitas variabel independen kepemilikan manajerial adalah sebesar 0,0000 atau lebih kecil sama dengan 0,05 yang berarti terdapat pengaruh signifikan antara kepemilikan manajerial terhadap nilai perusahaan. Nilai signifikansi probabilitas variabel independen kepemilikan institusional adalah sebesar 0,6936 atau lebih besar sama dengan 0,05 yang berarti tidak terdapat pengaruh signifikan antara kepemilikan manajerial terhadap nilai perusahaan. Nilai signifikansi probabilitas variabel independen profitability adalah sebesar 0,0000 atau lebih kecil sama dengan 0,05 yang berarti terdapat pengaruh signifikan antara profitability terhadap nilai perusahaan. Berdasarkan Uji-F, nilai probability F-statistic sebesar 0,000004. Hal ini menandakan bahwa good corporate governance (kepemilikan manajerial dan kepemilikan institusional) dan profitability secara bersama-sama mampu mempengaruhi nilai perusahaan secara signifikan. Berdasarkan paparan hasil uji koefisien determinasi, nilai Adjusted $R$-squared adalah sebesar 0,567699 atau sebesar 56,77\%. Hal ini 
menjelaskan bahwa variabel nilai perusahaan sebesar $56,77 \%$ dijelaskan oleh variabel kepemilikan manajerial, kepemilikan institusional dan profitabilitas. Sedangkan sisanya sebesar 43,23\% dijelaskan oleh variabel lain di luar dari variabel independen dalam penelitian ini. Namun untuk membuktikan bahwa model regresi ini tidak terjadi gejala multikolinearitas maka dilakukan pengujian korelasi antara variabel independen.

Tabel 5. Hasil Uji Multikolinearitas

\begin{tabular}{lccc}
\hline & $\begin{array}{c}\text { KEPEMILIKAN } \\
\text { MANAJERIAL }\end{array}$ & $\begin{array}{c}\text { KEPEMILIKAN } \\
\text { INSTITUSIONAL }\end{array}$ & PROFITABILITY \\
\hline \hline KEPEMILIKAN & & & \\
MANAJERIAL & 1.000000 & - & - \\
\hline KEPEMILIKAN & & & - \\
INSTITUSIONAL & $\mathbf{- 0 . 3 9 2 0 0 8}$ & 1.000000 & 1.000000 \\
\hline PROFITABILITY & $\mathbf{- 0 . 2 3 6 4 0 6}$ & $\mathbf{0 . 3 5 6 9 8 3}$ & \\
\hline
\end{tabular}

Sumber: hasil pengolahan Eviews 10

Tabel 5 menunjukan tidak terdapat korelasi antar variabel independen yaitu kepemilikan manajerial, kepemilikan institusional dan profitabilitas Nilai korelasi tidak melebihi angka 0.80 sehingga menunjukkan bahwa tidak dideteksi multikolinearitas antar variabel independen pada model penelitian ini.

\section{DISKUSI}

\section{Pengaruh Kepemilikan Manajerial Terhadap Nilai Perusahaan}

Hasil menunjukkan bahwa terdapat pengaruh signifikan antara kepemilikan manajerial terhadap nilai perusahaan manufaktur sektor consumer goods yang terdaftar di BEI periode 2017-2019. Hal ini berarti apabila nilai kepemilikan manajerial meningkat, nilai perusahaan ikut meningkat. Hasil yang sama dengan penelitian ini ditunjukkan dengan penelitian yang dilakukan oleh Linda Safitri dan Nyoman (2019) menunjukkan bahwa kepemilikan manajerial memiliki pengaruh signifikan dan positif terhadap nilai perusahaan. Hal ini menunjukkan bahwa Konflik keagenan dapat dikurangi dengan adanya kepemilikan manajerial sebagai penyeimbang kepentingan antara pemegang saham dan manajer.

\section{Pengaruh Kepemilikan Manajerial Terhadap Nilai Perusahaan}

Hasil penelitian menunjukkan bahwa kepemilikan institusional tidak memiliki pengaruh terhadap nilai perusahaan pada perusahaan manufaktur sektor consumer goods yang terdaftar di BEI periode 2017-2019. Hasil penelitian ini bertolak belakang dengan teori keagenan yang menyatakan jika kepemilikan institusional tinggi maka nilai perusahaan juga tinggi. Hasil penelitian ini sejalan dengan penelitian terdahulu yang dilakukan oleh Nukrim (2017) dan Nur Aini (2019) yang menyatakan bahwa kepemilikan institusional tidak memiliki pengaruh terhadap nilai perusahaan. Hal ini menunjukkan besarnya presentase kepemilikan saham dari luar perusahaan tidak mampu meningkatkan nilai perusahaan.

\section{Pengaruh Profitabilitas Terhadap Nilai Perusahaan}

Hasil penelitian ini menunjukkan bahwa profitabilitas memiliki pengaruh signifikan positif terhadap nilai perusahaan pada perusahaan manufaktur sektor consumer goods yang terdaftar di BEI periode 2017-2019. Hal ini menunjukkan apabila profitabilitas naik, maka nilai perusahaan juga naik. Hasil penelitian ini sejalan yang sejalan dengan penelitian yang dilakukan oleh Ria Nofrita (2009) dan Zulfa dkk yang menyatakan bahwa profitabilitas 
memiliki pengaruh positif dan signifikan terhadap nilai perusahaan. Nilai perusahaan dianggap baik jika perusahaan mampu meningkatkan laba yang membuat permintaan saham oleh investor terhadap perusahaan meningkat dan mampu meningkatkan kesejahteraan pemegang saham dan nilai perusahaan.

\section{PENUTUP}

Penelitian menghasilkan simpulan bahwa kepemilikan manajerial dan profitabilitas memiliki pengaruh signifikan terhadap nilai perusahaan. Namun demikian penelitian ini memiliki keterbatasan diantaranya, subyek dalam penelitian ini hanya terdiri dari perusahaanperusahaan manufaktur sektor consumer goods yang terdaftar di Bursa Efek Indonesia. Rentang waktu periode dalam penelitian ini hanya selama 3 tahun. Banyak perusahaan yang tidak mempunyai kepemilikan saham manajerial. Pada peneltian ini variabel nilai perusahaan (Tobin's Q) hanya dijelaskan oleh dua variabel independen yaitu good corporate governancedan profitabilitas. Maka dari itu beberapa saran yang dapat peneliti berikan kepada perusahaan manufaktur sektor consumer goods sebaiknya memperhatikan kepemilikan manajerial dan profitabilitas perusahaan karena hasil penelitian ini membuktikan secara signifikan bahwa kepemilikan manajerial dan profitabilitas mampu mempengaruhi nilai perusahaan. Penelitian selanjutnya diharapkan tidak hanya menggunakan sektor consumer goods sebagai subyek penelitian, namun bisa menambahkan sektor atau industri lainnya seperti industri aneka dan sektor industri dasar dan kimia, memperpanjang rentang waktu sampel penelitian sampai lima tahun dan seterusnya dan juga menambah variabel independen seperti ukuran dewan komisaris, komisaris independen, pertumbuhan perusahaan, dan ukuran perusahaan.

\section{DAFTAR PUSTAKA}

Al-Najjar, B., Al-Najjar, D. (2017). The Impact of External Financing on Firm Value and A Corporate Governance Index: SME Evidence. Journal of Small Business and Enterprise Development, 24 (2), 1.

Bagus, I., Solimun, S., Achmad, A., Rahayu., Mangesti, Sri. (2019). Corporate Governance, Corporate Profitability Toward Corporate Social Responsibility Disclosure and Corporate Value (Comparative Study in Indonesia, China dan India Stock Exchange in 2013-2016). Social Responsibility Journal, 16 (7), 983-999.

Duli, Nikolaus. 2019. Metodologi Penelitian Kuantitatif: Beberapa Konsep Dasar Untuk Penulisan Skripsi \& Analisis Data Dengan SPSS. Yogyakarta: CV Budi Utama.

Ekadjaja, M., Siswanto, H. P., Nuringsih, K., \& Amelinda, R. (2019). Parabolic Effect Between Managerial Ownership And Firm Value To Control Agency Conflict. Jurnal Manajemen, 23 (3), 355-374.

Endra, Febri. 2017. Pedoman Metodologi Penelitian: (Statistika Praktis). Taman Sidoarjo: Zifatama Jawara.

Handayani., Dwi, B., Rohman, A., Chariri, A., Pamungkas., Dapit, I. (2020). Corporate Financial Performance on Corporate Governance Mechanism and Corporate Value; Evidence from Indonesia. Montenegrin Journal of Economic, 16(3), 161-171.

Investasi Indonesia. (2018). Industri Manufaktur di Indonesia Sebagai Basis Produksi di ASEAN. Retrieved Januari 8, 2021, from https://www.investindonesia.go.id/id/artikelinvestasi/detail/perkembangan-industri-manufaktur-di-indonesia 
Karlina. (2020). Inilah Penjelasan Tentang Saham Sektor Consumer Goods .Retrieved Januari 8, 2021, from https://astronacci.com/blog/read/inilah-penjelasan-tentang-saham-sektorconsumer-goods

Kementrian Perindustrian Republik Indonesia. (2019). Industri Manufaktur Berperan Penting Genjot Investasi dan Ekspor Retrieved, Januari 8, 2021, from, https://kemenperin.go.id/artikel/20091/Industri-Manufaktur-Berperan-Penting-GenjotInvestasi-dan-Ekspor-

Susanto, W., \& Nuringsih, K. (2020). The Parabolic Effect of Managerial Ownership and the Impact TowardFirm's Performance. Jurnal Ekonomi, 25 (2), 233-250. 